\title{
GMR
}

\section{Feline immunodeficiency virus and feline leukemia virus: frequency and associated factors in cats in northeastern Brazil}

L.C. Lacerda, A.N. Silva, J.S. Freitas, R.D.S. Cruz, R.A. Said and

A.D. Munhoz

Departamento de Ciências Agrárias e Ambientais, Universidade Estadual de Santa Cruz, Ilhéus, BA, Brasil

Corresponding author: A.D. Munhoz

E-mail: munhoz@uesc.br

Genet. Mol. Res. 16 (2): gmr16029633

Received January 30, 2017

Accepted March 3, 2017

Published May 10, 2017

DOI http://dx.doi.org/10.4238/gmr16029633

Copyright $\left({ }^{\circ} 2017\right.$ The Authors. This is an open-access article distributed under the terms of the Creative Commons Attribution ShareAlike (CC BY-SA) 4.0 License.

\begin{abstract}
Our aims were to determine the frequencies of feline immunodeficiency virus (FIV) and feline leukemia virus (FeLV) in owned and stray cats in the northeastern region of Brazil, ascertain the status of FeLV infection, and investigate potential associated factors among the owned cats. Blood samples from 200 asymptomatic owned cats and 30 stray cats were processed using nested PCR and commercial immunochromatographic tests to diagnose infections. To evaluate the factors associated with FIV and/or FeLV in owned cats, a semistructured interview was conducted with each owner about the animal's environment, and these data were subjected to unconditional logistic regression. The frequencies for owned cats were 6\% (12/200) and 3\% (6/200) for FIV and FeLV, respectively. No owned cat was positive for both viruses. Stray cats showed frequencies of $6.66 \%(2 / 30)$ and $0 \%(0 / 30)$ for FIV and FeLV, respectively. Contact with other cats and living in peri-urban areas were considered to be risk factors $(\mathrm{P}<0.05)$ for FIV. We did not identify any factors associated with infections with
\end{abstract}

Genetics and Molecular Research 16 (2): gmr16029633 
FeLV. Our results confirm the presence of these two retroviruses in the region under study. Our use of different diagnostic techniques allowed us to determine the frequency of retroviruses in the feline population more accurately, particularly with regard to infections by FeLV, which have complex pathogenesis.

Key words: Retrovirus; Owned cats; Epidemiology; Stray cats; Feline immunodeficiency virus; Feline leukemia virus

\section{INTRODUCTION}

The feline immunodeficiency virus (FIV) and the feline leukemia virus (FeLV) are two clinically important retroviruses that affect the health of domestic and wild felids around the world (Courchamp et al., 1997; Hartmann, 2011; Filoni et al., 2012). The distribution of animals infected with these retroviruses varies considerably depending on the geographic region, the feline population evaluated, and the diagnostic method chosen (Luria et al., 2004; Levy et al., 2008; Gleich et al., 2009). This explains the variations of seroprevalence from 2.5 to $31.3 \%$ for FIV and from 2.3 to $30.4 \%$ for FeLV that have been found in studies from different parts of the world (Arjona et al., 2000; Levy et al., 2006; Bande et al., 2012). In Brazil, the seroprevalence ranges from 5.6 to $16.7 \%$ for FIV and from 0.33 to $32.5 \%$ for FeLV (Teixeira et al., 2007; Macieira et al., 2008; Sobrinho et al., 2011) and, additionally, the infection rates found using molecular tests have ranged from 2 to $15.7 \%$ for FIV and from 0.5 to $47.5 \%$ for FeLV (Coelho et al., 2011; Marçola, 2011; Silva et al., 2014).

The risk factors associated with the presence of FIV and/or FeLV are closely related to the infection routes of the virus and the susceptibility of the host. Sexually intact male and aggressive cats that have access to the streets or that live in areas with high population density are at greater risk of coming into contact with the agents (Levy et al., 2006; Gleich et al., 2009; Greggs et al., 2011).

Serological testing to search for FIV antibodies and FeLV p27 antigen is the most common routine clinical technique. Performing this testing in association with polymerase chain reaction (PCR) not only enables identification of the provirus, independently of the presence of FIV antibodies or of FeLV antigenemia, but also makes it possible to determine the different outcomes from infection by FeLV (Herring et al., 2001; Hofmann-Lehmann et al., 2001; Englert et al., 2012).

Given the importance and severity of FIV and FeLV infections in cats, and the lack of information about these infections in northeastern Brazil, this observational study aimed to determine the frequencies of these two retroviruses in owned cats and stray cats using complementary molecular and serological tests. Additionally, this study aimed to investigate possible factors associated with infection among owned cats.

\section{MATERIAL AND METHODS}

\section{Location of the study and sampling design}

Between February 2012 and April 2013, we carried out an epidemiological study of analytical cross-sectional design in the cities of Ilhéus (14 $\left.47^{\prime \prime} \mathrm{S} ; 39^{\circ} 02^{\prime \prime} \mathrm{W}\right)$ and Itabuna 
$\left(14^{\circ} 47^{\prime \prime} \mathrm{S} ; 39^{\circ} 16^{\prime \prime} \mathrm{W}\right)$, which are within the microregion of Ilhéus-Itabuna, Bahia, Brazil. Through non-probability sampling, 200 cat owners were selected from the records of veterinary clinics in the region. Blood samples were collected from these animals in their homes. The inclusion criteria were: 1) it needed to be asymptomatic, i.e., clinical examination did not show any abnormalities suggestive of systemic disease such as vomiting, diarrhea, weight loss, nasal secretion, or neoplasia (Collado et al., 2012), 2) it had to be 6 months of age or over. In addition to these animals, 30 samples from stray cats were sent by veterinarians at the zoonosis control centers of these cities. We did not have any information on the health status of the stray cats. The study was conducted in accordance with the principles of bioethics and animal welfare, under the protocol number 011/12 (CEUA/UESC).

\section{Factors associated}

To evaluate factors associated with FIV and/or FeLV positivity, a semi-structured questionnaire was completed for each sampled cat. The data recorded included: gender, age $(<2$ years $v s \geq 2$ years), pure breed, castrated, fight history, bites history, living in apartment, living in peri-urban area, contact with other cats, city (Itabuna vs Ilhéus), and FIV and/or FeLV status.

\section{Serological tests for FIV and FeLV}

We tested the serum samples through commercial immunochromatographic tests: the FIV ac/FeLV Ag Test Kit (Alere $\left.{ }^{\circledR}\right)$, following the manufacturer's recommendations.

\section{Extraction of genomic DNA and PCR for FIV and FeLV}

We extracted genomic DNA from total blood using a commercial kit (QIAamp DNA Blood Minikit; Qiagen ${ }^{\mathrm{TM}}$ ), following the manufacturer's recommendations. All the samples were subjected to nested PCR for FIV and FeLV. The samples that presented negative results underwent a reaction to the gene of the GAPDH enzyme. Table 1 presents the primers used for each nested PCR (FIV, FeLV, and GAPDH).

Table 1. Primers used in nested PCR for FIV, FeLV, and GAPDH in the cats studied.

\begin{tabular}{|c|c|c|c|c|}
\hline Region & Sequence (5'-3') & Region & Product (bp) & Reference \\
\hline \multicolumn{5}{|l|}{ FIV } \\
\hline $\mathrm{A} 2$ & AAT ATG ACT GTA TCT ACT GC & \multirow[t]{2}{*}{ gag } & & \multirow[t]{2}{*}{ Hohdatsu et al., 1998} \\
\hline S2 & TTT TCT TCT AGA GTA CTT TCT GG & & & \\
\hline NS & TAT TCA AAC AGT AAA TGG AG & \multirow[t]{2}{*}{ gag } & \multirow[t]{2}{*}{329} & \multirow{2}{*}{ Hohdatsu et al., 1998} \\
\hline NA & CTG CTT GTT GTT CTT GAG TT & & & \\
\hline \multicolumn{5}{|c|}{ (2) } \\
\hline U3-F & ACA GCA GAA GTT TCA AGG CC & \multirow[t]{2}{*}{ U3/gag } & & \multirow[t]{2}{*}{ Miyazawa and Jarrett, 1997} \\
\hline G-R & GAC CAG TGA TCA AGG GTG AG & & & \\
\hline $\mathrm{U} 3-\mathrm{F}(2)$ & GCT CCC CAG TTG ACC AGA GT & \multirow[t]{2}{*}{ U3/gag } & \multirow[t]{2}{*}{601} & \multirow[t]{2}{*}{ Miyazawa and Jarrett, 1997} \\
\hline G-R(2) & GCT TCG GTA CCA AAC CGA AA & & & \\
\hline \multicolumn{5}{|l|}{ GAPDH } \\
\hline GAPDH-F & CCT TCA TTG ACC TCA ACT ACAT & & \multirow[t]{2}{*}{400} & \multirow[t]{2}{*}{ Birkenheuer et al., 2003} \\
\hline GAPDH-R & CCA AAG TTG TCA TGG ATG ACC & & & \\
\hline
\end{tabular}

For amplification of the proviral DNA of FIV, we carried out nested PCR in which the two reactions, each with a final volume of $25 \mu \mathrm{L}$, were composed of: $10 \mathrm{X}$ buffer; $2.0 \mathrm{mM}$ $\mathrm{MgCl}_{2} ; 0.2 \mathrm{mM}$ of each dNTP; $1 \mu \mathrm{M}$ of each primer; and $1.25 \mathrm{U}$ Taq DNA polymerase. In the

Genetics and Molecular Research 16 (2): gmr16029633 
first reaction, we added $5 \mu \mathrm{L}$ DNA of the sample to be tested, and $2 \mu \mathrm{L}$ of the product from this reaction was used to perform the second reaction. Ultrapure sterile water was used to complete the final volume of the reactions. The two reactions used the same amplification protocol, consisting of initial denaturation at $95^{\circ} \mathrm{C}$ for $5 \mathrm{~min}$, followed by 30 cycles at $95^{\circ} \mathrm{C}$ for $45 \mathrm{~s}$, $58^{\circ} \mathrm{C}$ for $45 \mathrm{~s}$ and $72^{\circ} \mathrm{C}$ for $45 \mathrm{~s}$, and a final extension at $72^{\circ} \mathrm{C}$ for $5 \mathrm{~min}$. The composition of the reactions and amplification protocols was adapted from Marçola (2011).

To assess the proviral DNA of FeLV, we carried out nested PCR. Both reactions presented final volumes of $25 \mu \mathrm{L}$, containing $10 \mathrm{X}$ buffer; $2.0 \mathrm{mM} \mathrm{MgCl}$; $0.2 \mathrm{mM}$ of each $\mathrm{dNTP} ; 0.4 \mu \mathrm{M}$ of each primer; and 1.25 U Taq DNA polymerase. In the first reaction, we added $5 \mu \mathrm{L}$ DNA of the sample to be tested, and $2 \mu \mathrm{L}$ of the product from this reaction was used to perform the second reaction. We used ultrapure sterile water to complete the final volume of the reactions. The amplification protocols consisted of initial denaturation at $94^{\circ} \mathrm{C}$ for $7 \mathrm{~min}$, followed by 33 cycles at $94^{\circ} \mathrm{C}$ for $55 \mathrm{~s}, 55.3^{\circ} \mathrm{C}$ for $55 \mathrm{~s}$ in the first reaction and $59.5^{\circ} \mathrm{C}$ for $55 \mathrm{~s}$ in the second reaction, and $72^{\circ} \mathrm{C}$ for $1 \mathrm{~min}$ and $10 \mathrm{~s}$; with a final extension at $72^{\circ} \mathrm{C}$ for $7 \mathrm{~min}$. The composition of the reactions and amplification protocols was adapted from Guimarães (2008).

To verify the integrity of the DNA and the absence of potential inhibitors, we subjected negative samples to PCR for the gene of the GAPDH enzyme. The reaction, with a final volume of $25 \mu \mathrm{L}$, comprised $10 \mathrm{X}$ buffer; $2.0 \mathrm{mM} \mathrm{MgCl}_{2} ; 0.2 \mathrm{mM}$ of each dNTP; and $1.25 \mathrm{U}$ Taq DNA polymerase with $5 \mathrm{U} / \mu \mathrm{L}$ and $5 \mu \mathrm{L}$ DNA of the sample to be tested. The amplification protocol consisted of initial denaturation at $95^{\circ} \mathrm{C}$ for $5 \mathrm{~min}$, followed by 40 cycles at $94^{\circ} \mathrm{C}$ for $30 \mathrm{~s}, 52^{\circ} \mathrm{C}$ for $1 \mathrm{~min}$ and $72^{\circ} \mathrm{C}$ for $1 \mathrm{~min}$, with a final extension at $72^{\circ} \mathrm{C}$ for $5 \mathrm{~min}$. The composition of the reactions and amplification protocols was adapted from Marçola (2011).

\section{Statistical analysis}

The results from the nested PCR and serological tests on both retroviruses, together with the data obtained in the interviews, were tabulated and subjected to Spearman's correlation $(\mathrm{P} \leq 0.8)$ to determine collinearity, through the Bioestat 5.0 ${ }^{\circledR}$ software, thus forming the preliminary model for unconditional logistic regression. We built the final model through input and output of variables (backward system), using EPI INFO version 3.5.2.

\section{RESULTS}

Among the 200 owned animals in this study, we found that the frequency of FIVpositive animals was $6 \%(12 / 200$; $95 \% \mathrm{CI}$ : $3.1-10.2 \%)$ through using the two techniques. Of these, seven were positive to both tests, one was positive only for nested PCR and four were positive only for FIV antibodies. In diagnosing FeLV, 3\% (6/200; 95\%CI: 1.1-6.4\%) were positive for FeLV, among which one was positive in both tests, three were positive only in the nested PCR and two were positive only for the FeLV p27 antigen. Among the stray cats, the frequency of animals positive for FIV was $6.6 \%$ (2/30; 95\%CI: 10.8-22.1\%) through the two techniques and no animals were positive for FeLV. No owned cat was positive for both viruses. All the samples that were negative for FIV or FeLV tested positive for GAPDH.

In the population of owned cats, the variables "living in peri-urban area" and "contact with other cats" were risk factors for FIV in the logistic regression (Table 2). None of the variables was significant for FeLV in unconditional logistic regression. We did not perform

Genetics and Molecular Research 16 (2): gmr16029633 
any multivariate analysis on the stray cats because of the lack of information on the animals that formed the study sample.

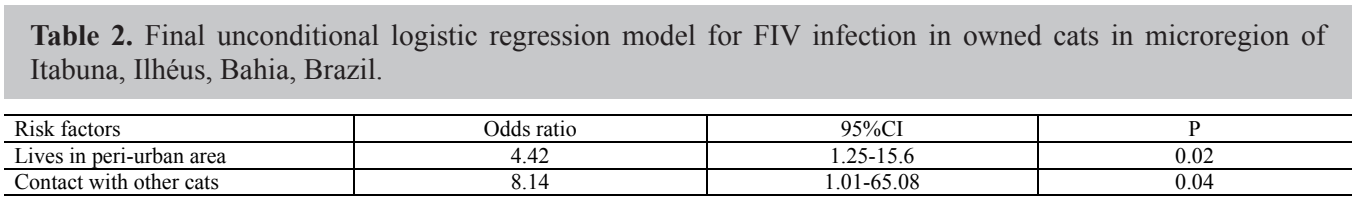

\section{DISCUSSION}

Among the 200 owned cats, the results demonstrated that both FIV and FeLV were present at low frequencies, thus corroborating the results from other epidemiological studies that were also conducted among owned cats that lacked clinical or laboratory signs that might suggest infections (Reche Jr et al., 1997; Arjona et al., 2000; Caxito et al., 2006). On the other hand, in studies on hospitalized animals and animals showing clinical and laboratory signs compatible with these infections, the prevalence values are commonly found to be higher (Macieira et al., 2008; Coelho et al., 2011).

Control and prophylaxis procedures such as rapid tests for diagnosis and vaccination were listed by Gleich et al. (2009) as the possible reasons for the low seroprevalence of FeLV found in their study. However, these procedures have not yet become commonly used in routine care in the region studied here, and this is partially because of the lack of information on the prevalence of infections caused by retroviruses. In Brazil, vaccine is only available for FeLV. The high mortality rate induced by FeLV (Addie et al., 2000) and the different courses of the infection that can develop through virus-host interactions may also explain the low frequency of infection that we observed in our study.

We did not observe any coinfections between these retroviruses, which suggest that the agents present different locations, or even that FIV- and FeLV-positive animals may die more quickly due to synergism and potentiation effects caused by the two retroviruses. Pedersen et al. (1990) showed that FeLV-positive animals infected experimentally with FIV presented anorexia, fever, diarrhea, weight loss, and leukopenia with greater severity. The study conducted by Courchamp et al. (1997) supports this claim, through reporting that the impact of coinfection among retroviruses is greater than the sum of the effects of each disease examined separately.

As a complementary investigation, we performed serological tests and nested PCR on all animals. Among the FIV-positive animals, four cats were only positive for the presence of antibodies. We excluded the factors that could alter the frequency results, such as animals below 6 months of age, which might still have maternal antibodies against FIV. In Brazil, the FIV vaccine is not available yet, and therefore will not have interfered with the results. However, a PCR test negative for FIV may reflect a level of viral nucleic acid below the detection limit, or an FIV strain that is not detected by the assay (Little et al., 2011). In addition, PCR for GAPDH was performed on the negative samples, thus ensuring the integrity of the DNA. However, false positives are not uncommon in serological tests (Tozon et al., 2008). Thus, we also found that one cat was only positive through the nested PCR: this animal was possibly at an early stage of infection (when the proviral DNA can be detected in the peripheral blood before antibodies can) (Ohkura et al., 1997). Among the FeLV-positive animals, we found

Genetics and Molecular Research 16 (2): gmr16029633 
three cats that were negative for $\mathrm{p} 27$ and positive through nested PCR, which suggests that regressive/latent infections were present in these animals. The primers that we used in our study are able to detect three types of FeLV (A, B, C), thus allowing confirmation of the presence of exogenous proviral DNA for FeLV in blood cells (Miyazawa and Jarrett, 1997).

The factors associated with infections by FIV most commonly seen in the literature consulted were gender, age, history of fights, and access to the streets, which were all related to transmission of the virus through bites (Arjona et al., 2000; Levy et al., 2006). In our study, contact with other cats was correlated with infection, although the owners did not identify aggressive behavior in relation to other cats. Addie et al. (2000) proposed that FIV transmission is possible even without the presence of aggression among cats, such that mutual contact between FIV-positive cats and susceptible cats, or sharing of feeding bowls, could be sufficient for transmission of viruses. We also made a correlation between living in peri-urban areas and higher chances of contact between negative cats and FIV-infected cats. These results indicate that this retrovirus is distributed heterogeneously in our region.

Through analyzing the results from the population of stray cats, we expected to find higher frequencies of these two retroviruses, given that these animals may have constant intimate interaction with several other cats. However, this was not confirmed. In our study, we observed similar frequencies among owned cats and stray cats, as also observed by Lee et al. (2002) and Luria et al. (2004). These findings contribute towards the hypothesis that in the populations studied there is a low level of endemic disease, although the small number of samples from the stray cat population may also have affected the results.

This study showed the presence of both of these retroviruses in this region. Use of different diagnostic techniques allowed us to determine their frequencies in feline populations more accurately, particularly with regard to infections by FeLV, which has complex pathogenesis. Lastly, given that the presence of infected animals in the region under study has been confirmed, it is necessary to adopt preventive measures, through use of the vaccines available, investigations on the serological status of new pets, and restriction of access to the streets.

\section{ACKNOWLEDGMENTS}

The authors would like to thank all owners and the zoonosis control centers of the cities of Ilhéus and Itabuna for allowing us to collect the samples. We also thank Prof. João Pessoa Araújo Júnior of the Department of Microbiology and Immunology, Botucatu Institute of Bioscience, UNESP, Botucatu, São Paulo, Brazil, for making positive controls for FIV and FeLV available to us. Research supported by UESC, Ilhéus, Bahia, Brazil.

\section{REFERENCES}

Addie DD, Dennis JM, Toth S, Callanan JJ, et al. (2000). Long-term impact on a closed household of pet cats of natural infection with feline coronavirus, feline leukaemia virus and feline immunodeficiency virus. Vet. Rec. 146: 419-424. http://dx.doi.org/10.1136/vr.146.15.419

Arjona A, Escolar E, Soto I, Barquero N, et al. (2000). Seroepidemiological survey of feline leukemia vírus in Madrid and correlation with some clinical aspects. J. Clin. Microbiol. 38: 3448-3449.

Bande F, Arshad SS, Hassan L, Zakaria Z, et al. (2012). Prevalence and risk factors of feline leukaemia virus and feline immunodeficiency virus in peninsular Malaysia. BMC Vet. Res. 8: 33. http://dx.doi.org/10.1186/1746-6148-8-33

Birkenheuer AJ, Levy MG and Breitschwerdt EB (2003). Development and evaluation of a seminested PCR for detection and differentiation of Babesia gibsoni (Asian genotype) and B. canis DNA in canine blood samples. J. Clin. Microbiol.

Genetics and Molecular Research 16 (2): gmr16029633 
Feline immunodeficiency virus and feline leukemia virus

41: 4172-4177. http://dx.doi.org/10.1128/JCM.41.9.4172-4177.2003

Caxito FA, Coelho FM, Oliveira ME and Resende M (2006). Phylogenetic analysis of feline immunodeficiency virus strains from State of Minas Gerais, Brazil. Arq. Bras. Med. Vet. Zoo. 58: 1222-1225.

Coelho FM, Maia MQ, Luppi, MM, Costa EA, et al. (2011). Ocorrência do vírus da leucemia felina em Felis cattus em Belo Horizonte. Arq. Bras. Med. Vet. Zootec. 63: 778-783.

Collado VM, Domenech A, Miro G, Martin S, et al. (2012). Epidemiological Aspects and Clinicopathological Findings in Cats Naturally Infected with Feline Leukemia Virus (FeLV) and/or Feline Immunodeficiency Virus (FIV). Open J. Vet. Med 2: 13-20. http://dx.doi.org/10.4236/ojvm.2012.21003

Courchamp F, Suppo C, Fromont E and Bouloux C (1997). Dynamics of two feline retroviruses (FIV and FeLV) within one population of cats. Proc. Biol. Sci. 264: 785-794. http://dx.doi.org/10.1098/rspb.1997.0111

Englert T, Lutz H, Sauter-Louis C and Hartmann K (2012). Survey of the feline leukemia virus infection status of cats in Southern Germany. J. Feline Med. Surg. 14: 392-398. http://dx.doi.org/10.1177/1098612X12440531

Filoni C, Catão-Dias JL, Cattori V, Willi B, et al. (2012). Surveillance using serological and molecular methods for the detection of infectious agents in captive Brazilian neotropic and exotic felids. J. Vet. Diagn. Invest. 24: 166-173. http://dx.doi.org/10.1177/1040638711407684

Gleich SE, Krieger S and Hartmann K (2009). Prevalence of feline immunodeficiency virus and feline leukaemia virus among client-owned cats and risk factors for infection in Germany. J. Feline Med. Surg. 11: 985-992. http://dx.doi. org/10.1016/j.jfms.2009.05.019

Greggs WM, 3rd, Clouser CL, Patterson SE and Mansky LM (2011). Broadening the use of antiretroviral therapy: the case for feline leukemia virus. Ther. Clin. Risk Manag. 7: 115-122.

Guimarães AMS (2008). Detecção de Micoplasmas, Bartonelas e Vírus da Leucemia Felina em pequenos felídeos neotropicais mantidos em cativeiro no refúgio Bela Vista, Foz do Iguaçu. Dissertação. Universidade de São Paulo, São Paulo.

Hartmann K (2011). Clinical aspects of feline immunodeficiency and feline leukemia virus infection. Vet. Immunol. Immunopathol. 143: 190-201. http://dx.doi.org/10.1016/j.vetimm.2011.06.003

Herring ES, Troy GC, Toth TE, Forrester SD, et al. (2001). Detection of feline leukaemia virus in blood and bone marrow of cats with varying suspicion of latent infection. J. Feline Med. Surg. 3: 133-141. http://dx.doi.org/10.1053/ jfms.2001.0132

Hofmann-Lehmann R, Huder JB, Gruber S, Boretti F, et al. (2001). Feline leukaemia provirus load during the course of experimental infection and in naturally infected cats. J. Gen. Virol. 82: 1589-1596. http://dx.doi.org/10.1099/0022$\underline{1317-82-7-1589}$

Hohdatsu T, Motokawa K, Usami M, Amioka M, et al. (1998). Genetic subtyping and epidemiological study of feline immunodeficiency virus by nested polymerase chain reaction-restriction fragment length polymorphism analysis of the gag gene. J. Virol. Methods 70: 107-111. http://dx.doi.org/10.1016/S0166-0934(97)00167-5

Lee IT, Levy JK, Gorman SP, Crawford PC, et al. (2002). Prevalence of feline leukemia virus infection and serum antibodies against feline immunodeficiency virus in unowned free-roaming cats. J. Am. Vet. Med. Assoc. 220: 620622. http://dx.doi.org/10.2460/javma.2002.220.620

Levy J, Crawford C, Hartmann K, Hofmann-Lehmann R, et al. (2008). 2008 American Association of Feline Practitioners' feline retrovirus management guidelines. J. Feline Med. Surg. 10: 300-316. http://dx.doi.org/10.1016/j. jfms.2008.03.002

Levy JK, Scott HM, Lachtara JL and Crawford PC (2006). Seroprevalence of feline leukemia virus and feline immunodeficiency virus infection among cats in North America and risk factors for seropositivity. J. Am. Vet. Med. Assoc. 228: 371-376. http://dx.doi.org/10.2460/javma.228.3.371

Little S, Bienzle D, Carioto L, Chisholm H, et al. (2011). Feline leukemia virus and feline immunodeficiency virus in Canada: recommendations for testing and management. Can. Vet. J. 52: 849-855.

Luria BJ, Levy JK, Lappin MR, Breitschwerdt EB, et al. (2004). Prevalence of infectious diseases in feral cats in Northern Florida. J. Feline Med. Surg. 6: 287-296. http://dx.doi.org/10.1016/j.jfms.2003.11.005

Macieira DB, de Menezes RdeC, Damico CB, Almosny NRP, et al. (2008). Prevalence and risk factors for hemoplasmas in domestic cats naturally infected with feline immunodeficiency virus and/or feline leukemia virus in Rio de Janeiro-Brazil. J. Feline Med. Surg. 10: 120-129. http://dx.doi.org/10.1016/j.jfms.2007.08.002

Marçola TG (2011). Estudo da avaliação laboratorial e ocorrência da infecção pelo vírus da imunodeficiência felina e co-infecções em felinos domésticos de diferentes localidades do Distrito Federal. Dissertação. Universidade de Brasília, Brasília.

Miyazawa T and Jarrett O (1997). Feline leukaemia virus proviral DNA detected by polymerase chain reaction in antigenaemic but non-viraemic ('discordant') cats. Arch. Virol. 142: 323-332. http://dx.doi.org/10.1007/ $\underline{\mathrm{s} 007050050079}$

Genetics and Molecular Research 16 (2): gmr16029633 
Ohkura T, Shin YS, Wakamiya N, Iwa N, et al. (1997). Detection of proviruses and viral RNA in the early stages of feline immunodeficiency virus infection in cats: a possible model of the early stage of HIV infection. Exp. Anim. 46: 31-39. http://dx.doi.org/10.1538/expanim.46.31

Pedersen NC, Torten M, Rideout B, Sparger E, et al. (1990). Feline leukemia virus infection as a potentiating cofactor for the primary and secondary stages of experimentally induced feline immunodeficiency virus infection. J. Virol. 64: 598-606.

Reche Jr A, Hagiwara MK and Lucas SRR (1997). Clinical study of acquired immunodeficiency syndrome in domestic cats in São Paulo. Braz. J. Vet. Res. Anim. Sci. 34: 152-155.

Silva FS, Castro CC, Finger PF, Silva DS, et al. (2014). Ocorrência do subtipo B do vírus da imunodeficiência felina em gatos domésticos da região do Rio Grande do Sul, Brasil. Arq. Bras. Med. Vet. Zootec. 66: 1-6. http://dx.doi. org/10.1590/S0102-09352014000100001

Sobrinho LSV, Vides JP, Braga ET, Gomes AAD, et al. (2011). Sorofrequência de infecção pelo virus da imunodeficiência feline e virus da leukemia feline em gatos do município de Araçatuba, São Paulo. Braz. J. Vet. Res. Anim. Sci. 48: 378-383. http://dx.doi.org/10.11606/S1413-95962011000500004

Teixeira BM, Rajão DS, Haddad JPA, Leite RC, et al. (2007). Ocorrência do vírus da imunodeficiência felina e do vírus da leucemia felina em gatos domésticos mantidos em abrigos no município de Belo Horizonte. Arq. Bras. Med. Vet. Zootec. 59: 939-942. http://dx.doi.org/10.1590/S0102-09352007000400019

Tozon N, Nemec AS, Zemljic M, Zakosek M, et al. (2008). High prevalence of feline immunodeficiency vírus (FIV) and feline leucemia vírus (FeLV) in Slovenia. Acta Vet. (Beogr.) 58: 191-201. http://dx.doi.org/10.2298/AVB0803191T

Genetics and Molecular Research 16 (2): gmr16029633 